\title{
Vaccine allergy
}

\author{
Derek K. Chu MD PhD, Zainab Abdurrahman MMath MD
}

Cite as: CMAJ 2019 April 8;191:E395. doi: 10.1503/cmaj.190208

CMAJ Podcasts: author interview at https://soundcloud.com/cmajpodcasts/190208-five

1 Immunoglobulin E (IgE)-mediated vaccine allergies are uncommon, manifesting within minutes as urticaria, angioedema, wheeze or anaphylaxis Anaphylaxis to vaccines occurs in about 1 in 760000 vaccinations. ${ }^{1}$ Parenteral exposure means that reactions mediated by IgE begin within minutes of an injection, are unlikely to begin after more than 30 to 60 minutes, and are highly unlikely after 4 hours. ${ }^{2}$

2 The most common adverse events of vaccines are fever, local pain or irritation, and local redness or swelling, which are not signs of allergy With live vaccines, adverse effects can be delayed until 7 to 21 days after immunization; this includes vaccine-induced delayed-onset urticaria, which is commonly mistaken for allergy.

\section{Patients with egg allergy can be safely vaccinated with} several vaccines without any special precautions

The Public Health Agency of Canada and Canadian Paediatric Society state that certain vaccines (measles, mumps and rubella [MMR], influenza [all types - live or inactivated], varicella and rabies) contain such minuscule amounts of egg protein, which is also denatured, that they are safe for routine use in patients with egg allergy; ${ }^{2}$ no specialist evaluation or special precautions are required (Box 1)..$^{3,4}$

Vaccine allergies are typically unpredictable and specific to a single vaccine

Common exceptions to this are gelatin allergy (e.g., gummy bears, jelly dessert powder, marshmallows) that may trigger an allergic reaction to MMR, varicella or Japanese encephalitis vaccines; egg allergy and yellow fever vaccine; and latex allergy with exposure to rubber stoppers on multidose vials or in some preloaded syringes. ${ }^{5}$ Associations between yeast and and IgEmediated reactions to hepatitis $B$ or human papillomavirus vaccines are unlikely causal (Box 1$).^{5}$

\section{Even if patients are truly allergic to a vaccine,} allergists can often safely vaccinate them

Allergists can facilitate immunization of patients with vaccine allergy through techniques such as graded administration. ${ }^{5}$ Possible allergies to vaccines should not be a source of vaccine hesitancy for patients and health care providers.
Box 1: Summary of common vaccine allergy-related considerations $^{2-5 *}$

\begin{tabular}{|ll|}
\hline Allergy to ... & \multicolumn{1}{c|}{ Considerations for vaccination } \\
\hline $\begin{array}{l}\text { Egg } \\
\text { (common) }\end{array}$ & $\begin{array}{l}\text { - MMR, influenza (all types - live or attenuated), } \\
\text { varicella and rabies are safe for routine vaccination } \\
\text { without added precautions. }\end{array}$ \\
\hline $\begin{array}{l}\text { - Refer to allergist to facilitate vaccination for yellow fever } \\
\text { gummy bears) }\end{array}$ & $\begin{array}{l}\text { Refer to allergist to facilitate vaccination for MMR, } \\
\text { varicella or Japanese encephalitis }\end{array}$ \\
\hline Latex & $\begin{array}{l}\text { Avoid puncturing latex-containing stoppers of } \\
\text { multidose vials, or using preloaded syringes }\end{array}$ \\
\hline $\begin{array}{l}\text { Yeast } \\
\text { (uncommon, } \\
\text { questionable } \\
\text { association) }\end{array}$ & $\begin{array}{l}\text { Clarify whether there is a history of immediate-onset } \\
\text { allergic reaction to baker's or brewer's yeast (e.g., }\end{array}$ \\
$\begin{array}{l}\text { urticaria, angioedema, anaphylaxis in bakers or } \\
\text { beer-makers), and if possible or probable reaction, } \\
\text { refer to allergist to facilitate vaccination for hepatitis B } \\
\text { or human papillomavirus }\end{array}$
\end{tabular}

Note: $M M R=$ measles, mumps and rubella.

*If allergic to 1 of the above, consult an allergist for administration via graded exposure, to facilitate vaccination. Report any serious vaccine-induced reaction, whether allergic or not, to public health (http://bit.ly/VaccineAEFI) and refer the patient to the most appropriate specialist (e.g., encephalopathy to neurology; anaphylaxis to allergy).

\section{References}

1. McNeil MM, Weintraub ES, Duffy J, et al. Risk of anaphylaxis after vaccination in children and adults. J Allergy Clin Immunol 2016;137:868-78.

2. James JM, Burks AW, Roberson PK, et al. Safe administration of the measles vaccine to children allergic to eggs. N Engl J Med 1995;332:1262-6.

3. Addendum - LAIV use in egg allergic individuals Advisory Committee Statement (ACS) National Advisory Committee on Immunization (NACl). Canadian immunization guide chapter on influenza and statement on seasonal influenza vaccine for 2016-2017. Ottawa: Public Health Agency of Canada; 2016

4. Moore DL. Vaccine recommendations for children and youth for the $2017 / 2018$ influenza season. Paediatr Child Health 2018;23:e10-3.

5. Dreskin SC, Halsey NA, Kelso JM, et al. International Consensus (ICON): allergic reactions to vaccines. World Allergy Organ J 2016;9:32.

Competing interests: Zainab Abdurrahman reports receiving personal fees from Pfizer, outside the submitted work. No other competing interests were declared.

This article has been peer reviewed.

Affiliations: Departments of Medicine (Chu) and Pediatrics (Abdurrahman), Division of Clinical Immunology and Allergy, McMaster University, Hamilton, Ont.

Correspondence to: Derek Chu,chudk@mcmaster.ca 